Eixo Temático: Desenvolvimento de Estratégias Didáticas

\title{
ET-07-004 \\ RELATO DE EXPERIÊNCIA DIDÁTICA SOBRE O USO DOS JOGOS NA CONSTRUÇÃO DA APRENDIZAGEM DOS CONTEÚDOS DE BIOLOGIA
}

Nathalya Marillya de Andrade Silva, Márcia Adelino da Silva Dias, Diego Filipe Silva Araújo, Janaina Maria Pereira

Universidade Estadual da Paraíba - UEPB. Centro de Ciências Biológicas e da Saúde - CCBS. PIBID/CAPES/UEPB.

http://dx.doi.org/10.21472/congrebio2016.et-07-004

\section{RESUMO}

O presente trabalho traz um relato de experiência didática sobre o uso dos jogos na construção da aprendizagem dos conteúdos de biologia, com o objetivo de elaborar, confeccionar e divulgar jogos didáticos que auxiliem na compreensão e aprendizagem dos conteúdos de bioquímica relacionada à saúde e ácidos nucléicos. Pretende-se também, fazer uma reflexão sobre os resultados obtidos a partir da aplicação dessa atividade, a fim de impulsionar novas pesquisas nesse meio. Para o desenvolvimento deste estudo utilizou-se de uma pesquisa bibliográfica em relação aos jogos didáticos e aos conteúdos específicos. Baseado no lúdico enquanto estratégia de ensino, elaboramos os jogos de tabuleiro "A Bioquímica da Saúde" que aborda o diabetes, a aterosclerose, a obesidade e os prejuízos causados pelo sedentarismo, enfim a bioquímica relacionada á saúde de uma maneira geral e "DNA E RNA: Seu Código" que se refere à estrutura e função dos ácidos nucléicos, estes ao mesmo tempo em que tratam de conceitos de difícil compreensão favorecem o raciocínio, a argumentação, a interação entre alunos e entre professores e alunos, com o objetivo de facilitar a construção do conhecimento aos alunos de forma dinâmica, contemplando os interesses e necessidades dos mesmos. Os alunos que participaram da avaliação dos jogos eram de três salas (D, F, G) do primeiro ano do ensino médio da escola pública Dr. Hortênsio de Sousa Ribeiro - PREMEN, na cidade de Campina Grande/PB, um total de 95 participantes, dois professores, duas bolsistas e 91 alunos. Esse trabalho nos mostra que o jogo é um instrumento importante no ensino e na construção do aprendizado por tratar de forma dinâmica e divertida de conteúdos complexos. O diferencial do lúdico é a aproximação do jogo às teorias, e não apenas uma listagem dissociada de receitas de brincadeiras, e a proposição de alternativas de lugar para o jogo. Sua eficácia no processo ensino-aprendizado foi facilmente observada durante a aplicabilidade do jogo, e depois confirmada nas citações feitas por alunos e professores na produção de seus comentários. (CAPES/PIBID/UEPB).

Palavras-chave: Metodologias; Jogos; Aprendizagem; Ensino.

\section{INTRODUÇÃO}

A Lei de Diretrizes e Bases da educação nacional- LDB propõe no Capitulo II, Seção V, do Ensino Médio, art. 35, IV - a compreensão dos fundamentos científico-tecnológicos dos processos produtivos, relacionando a teoria com a prática, no ensino de cada disciplina. $\mathrm{E}$ ainda no art. 36, II - adotará metodologias de ensino e de avaliação que estimulem a iniciativa dos estudantes. (BRASIL, 1996). Nessa perspectiva a utilização de jogos didáticos, é uma estratégia importante para auxiliar no processo ensino-aprendizagem, é ainda um instrumento fundamental ao professor na abordagem de conceitos de difícil compreensão. Conceitos complexos quando apresentados por intermédio de um jogo didático, torna o conteúdo mais 
atrativo e divertido, despertando a curiosidade e a motivação do aluno, torna a aula mais interativa e consequentemente há um aprendizado significativo. Outra característica do jogo é a coletividade, importantíssima para o desenvolvimento das habilidades do aluno, pois simula a vida em grupo. Nesse aspecto são necessárias práticas de ensino inovadoras que promovam a efetiva integração do aluno à aprendizagem, incentivando uma participação ativa e melhorando a comunicação aluno-professor, tornando este momento significativo para as partes envolvidas no ensino e aprendizagem. Portanto, temos no jogo didático um método facilitador de ensino.

Para o professor moderno, entretanto, a escolha adequada das atividades de ensino é uma etapa importante em sua profissão. É nesta tarefa que se manifesta a verdadeira contribuição de seu métier. Assim como a competência profissional do engenheiro se manifesta na escolha de materiais e métodos de construção a idoneidade profissional do professor se manifesta na escolha de atividades de ensino adequadas aos objetivos educacionais, aos conteúdos de matéria e aos alunos (BORDENAVE, 2010).

De acordo com as Orientações Curriculares para o Ensino Médio o jogo oferece o estímulo e o ambiente propícios que favorecem o desenvolvimento espontâneo e criativo dos alunos e permite ao professor ampliar seu conhecimento de técnicas ativas de ensino, desenvolver capacidades pessoais e profissionais para estimular nos alunos a capacidade de comunicação e expressão, mostrando-lhes uma nova maneira, lúdica, prazerosa e participativa de relacionar-se com o conteúdo escolar, levando a uma maior apropriação dos conhecimentos envolvidos (BRASIL, 2006).

Notoriamente, os jogos didáticos, como as brincadeiras, os brinquedos e os jogos, são reconhecidos pela sociedade como meio de fornecer ao individuo um ambiente agradável, motivador, prazeroso, planejado e enriquecido, que possibilita a aprendizagem de várias habilidades. Outra importante vantagem, no uso dos jogos, é a tendência em motivar o aluno a participar espontaneamente na aula. Acrescenta-se a isso, o auxilio do caráter lúdico no desenvolvimento da cooperação, da socialização e das relações afetivas e, a possibilidade de utilizar jogos didáticos, como mediador na construção do conhecimento em qualquer área. Pode-se observar a relevâncias dos jogos didáticos que vão além do ensino/aprendizagem, mas auxiliam na simulação de valores que os educandos encontrarão durante sua vida, pois além de ensinar o conteúdo, são trabalhados implicitamente valores de cidadania.

As Orientações Educacionais Complementares aos Parâmetros Curriculares Nacionais $(\mathrm{PCN}+)$ no que se refere às estratégias para abordagens dos temas competentes ao ensino Médio, afirma que os jogos e brincadeiras são elementos muito valiosos no processo de apropriação do conhecimento. Permitem o desenvolvimento de competências no âmbito da comunicação, das relações interpessoais, da liderança e do trabalho em equipe, utilizando a relação entre cooperação e competição em um contexto formativo (BRASIL, 2000).

Diante das particularidades de cada educando as turmas são heterogêneas, desse modo o professor não deve limitar-se a uma estratégia de ensino ao abordar determinada temática, pois não conseguirá fornecer uma aprendizagem significativa a todos os alunos envolvidos. A utilização dos recursos didáticos é uma alternativa viável para dinamizar o aprendizado. Os recursos audiovisuais são cada vez mais empregados em nossas escolas, embora saibamos que em algumas regiões esta é uma realidade distante. O uso desses recursos possibilita ao aluno e ao professor expandir seus conhecimentos, o uso de imagens e vídeos, por exemplo, permite uma ampliação que não é possível quando se utiliza somente a lousa e o giz.

Com base no exposto acima, o PIBID/Biologia da Universidade Estadual da Paraíba, desenvolve projetos que investigam as possibilidades e os limites de propostas inovadoras no ensino de Biologia, baseadas no emprego de estratégias de ensino diversificadas. No âmbito da pesquisa, investigam-se estratégias, como: atividades práticas e experimentais, modelos, jogos didáticos, textos de divulgação cientifica, vídeos/filmes, dentre outros. 


\section{OBJETIVOS}

\subsection{Geral}

Divulgar a prática inovadora realizada na Escola de Educação Básica por licenciandos/estagiários graduandos em Biologia, para incentivar a profissão docente e mostrar aos futuros professores novas formas de estratégias didáticas e atuação em sala de aula.

\subsection{Específicos}

a) Criar jogos para abordar didaticamente conceitos específicos da Biologia.

b) Confeccionar, testar e avaliar a adequação dos jogos produzidos. interessados.

c) Divulgar os jogos produzidos entre os professores da rede escolar e outros

d) Propiciar aos acadêmicos-estagiários do Curso de Ciências Biológicas - Licenciatura, espaço para iniciação da prática pedagógica mediante a elaboração, implementação e avaliação de materiais didático.

\section{METODOLOGIA}

Em uma abordagem qualitativa foi explorado um plano de ação com uma proposta flexível cujos procedimentos adotados examinavam todo o contexto e interagia com os participantes, a realidade investigada era subjetiva e complexa, o instrumento de coleta de dados caracterizava-se por questões abertas e flexíveis explorando a interação pesquisadorentrevistado, a análise de dados foi interpretativa e descritiva com ênfase na análise de conteúdo e os resultados obtidos foram situacionais e limitados ao contexto.

\subsection{Produção dos jogos}

Os jogos de tabuleiro foram produzidos com base na bibliografia referente aos jogos didáticos e aos conteúdos específicos: carboidratos, proteínas, lipídios e ácidos nucléicos. Os alunos que participaram da avaliação dos jogos eram de três salas (D, F, G) do primeiro ano do ensino médio da escola pública Dr. Hortênsio de Sousa Ribeiro - PREMEN, na cidade de Campina Grande/PB, um total de 95 participantes, dois professores, duas bolsistas e 91 alunos. Para aplicação do jogo de tabuleiro, das palavras cruzadas e o desenvolvimento do texto pelos alunos foram necessárias duas aulas de 45 minutos cada, com total de $1 \mathrm{~h} 30 \mathrm{~min}$ para cada sala.

Na sala "D" a temática do tabuleiro era "A Bioquímica da Saúde”, participaram 32 alunos, o jogo abordava conteúdo sobre carboidratos, lipídios, proteínas e saúde. O tabuleiro foi confeccionado em E.V.A, utilizando-se, ainda, caneta hidrográfica e cola colorida. Os dados foram confeccionados em papel tipo ofício e tinta para tecido. Para os pinos utilizamos conchinhas do mar de diversas cores. Os materiais utilizados foram confeccionados anteriormente à aula e trazidos aos grupos de alunos. A turma foi dividida em grupos de quatro pessoas, os grupos formados receberam: 1 tabuleiro ilustrado contendo informações sobre 0 assunto e as regras do jogo, 1 dado, 4 pinos para que cada participante percorra o tabuleiro, 1 lista de charadas. Como mostra a figura: 


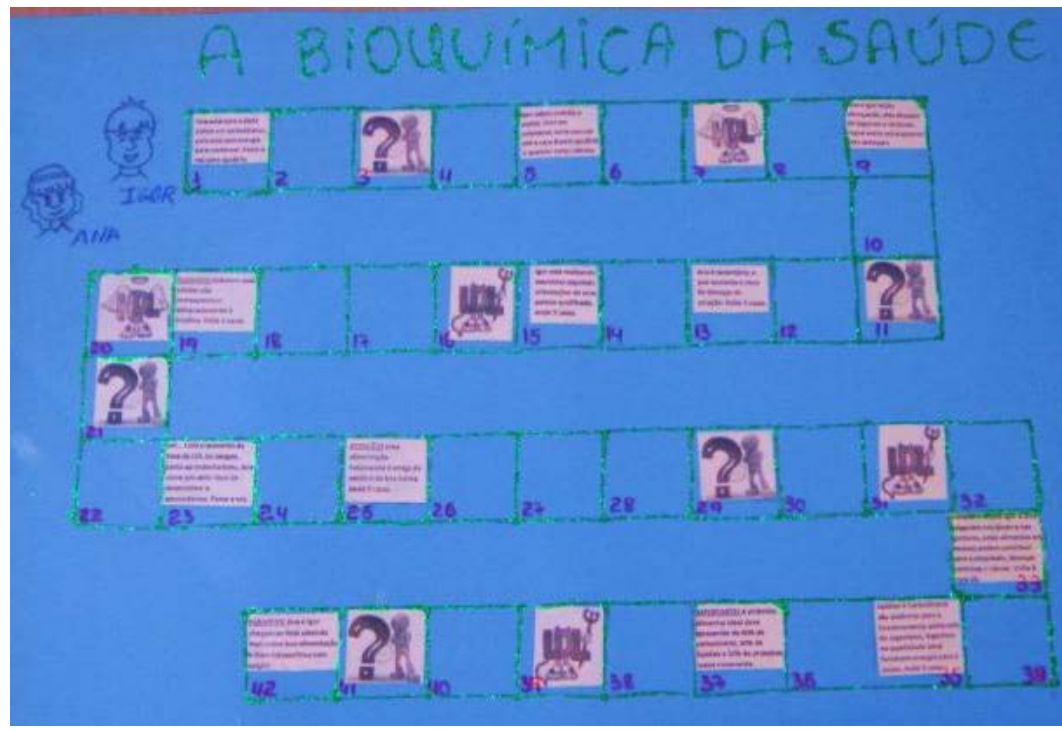

Figura 1. Jogo de tabuleiro “A BIOQUÍMICA DA SAÚDE”. Fonte: Arquivo Nathalya Silva.

Na sala "G” participaram 31 alunos e na sala "F” participaram 28 alunos. A temática do jogo referia-se ao conteúdo sobre estrutura e função dos ácidos nucléicos, foi intitulado "DNA e RNA: Seu código", utilizamos de 1h30min em cada turma para realização da atividade e avaliação da mesma. Este tabuleiro também foi confeccionado em E.V.A, utilizando-se, caneta hidrográfica e cola colorida. Os dados foram confeccionados em papel tipo ofício utilizando-se, ainda, tinta para tecido e para os pinos utilizamos conchinhas do mar coloridas. Todos estes materiais foram confeccionados anteriormente à aula e trazidos aos grupos de alunos. As turmas foram divididas em grupos de quatro alunos, os grupos formados receberam: 1 tabuleiro ilustrado e com as regras do jogo, 1 dado, 4 pinos para que cada participante percorra 0 tabuleiro, 1 sacolinha de afirmativas.

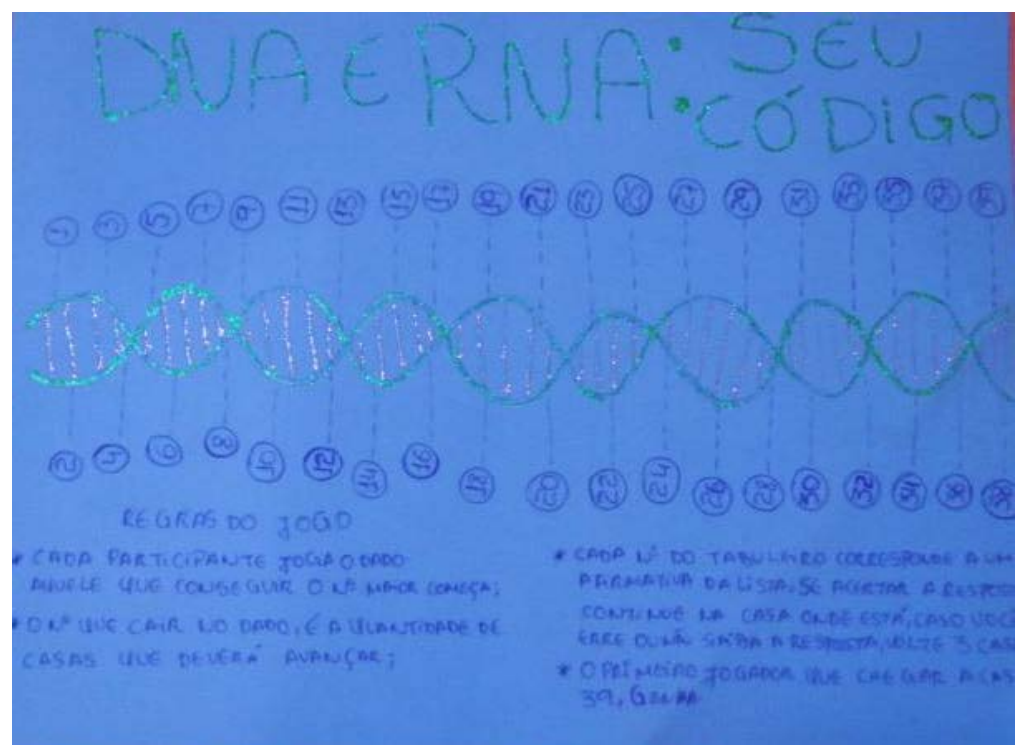

Figura 2. Jogo de tabuleiro “DNA E RNA: SEU CÓDIGO”. Fonte: Arquivo Nathalya Silva. 


\subsection{Regras do jogo}

\subsection{1 "A Bioquímica da saúde"}

* Cada participante joga o dado. Aquele que conseguir o número maior começa;

* Siga as instruções indicadas na casa onde cair;

* Se você cair numa casa ocupada pelo HDL, ande 7 casas;

* Se você cair numa casa ocupada pelo LDL, volte 7 casas;

* Se você cair numa casa ocupada pela interrogação (?), outro jogador lhe fará uma pergunta da lista de charadas, se você acertar a resposta, ande três casas, caso você erre ou não saiba a resposta, volte três casas;

* O primeiro jogador que chegar a casa 42, ganha.

\subsection{2 "DNA e RNA: seu código"}

* Cada participante joga o dado. Aquele que conseguir o no maior começa;

* O número que sair no dado equivale à quantidade de casas que você deverá avançar;

* Em cada casa que você parar, outro jogador vai ler pra você uma afirmativa da sacolinha, para você identificar se é uma afirmativa verdadeira ou falsa, se você acertar continue na casa que alcançou, caso você erre, volte 3 casas;

* O primeiro jogador a chegar a casa 38, ganha.

\section{RESULTADOS E DISCUSSÃO}

Na avaliação sobre a eficácia da atividade aos objetivos propostos na elaboração, podemos observar que o jogo didático colaborou no processo de ensino e aprendizagem, de forma diferenciada, dinâmica e atrativa. Por meio dessa atividade foi possível a elaboração de conceitos, reforço de conteúdos, promoveu a sociabilidade entre os alunos e trabalhou a criatividade, o espírito de competição e a cooperação. O jogo exerceu uma fascinação entre os alunos, que lutavam pela vitória procurando entender os mecanismos dos mesmos, o que constitui de uma técnica onde os alunos aprenderam brincando.

Foi aplicado a cada aluno, ao término do jogo, questões em forma de palavras cruzadas sobre a temática do tabuleiro para analisar o desenvolvimento de conhecimento pelos alunos. Em seguida foi proposto a cada aluno desenvolver um pequeno texto, que seguiam a um questionário-roteiro:

* O jogo didático ensinou algo novo sobre o tema abordado?

* Ajudou a esclarecer alguma dúvida?

* Qual a minha auto avaliação durante o desenvolvimento do jogo?

O professor de cada turma pôde acompanhar o desenvolvimento do jogo, e as avaliações destes para a inovadora metodologia de ensino apresentada foram bastante positivas. Os comentários foram: "Gostei muito do jogo, foi bem elaborado", "Os alunos gostaram bastante, gostei tanto que joguei também".

Na sala "D” a temática do tabuleiro era “A Bioquímica da Saúde”, os alunos participantes apresentaram poucas dificuldades no desenvolvimento do jogo de tabuleiro e das palavras cruzadas. Na sala "G" e na sala "F" a temática era "DNA e RNA: Seu código", a turma "G" apresentou maiores dificuldades que a turma "F" sobre a temática, mas não tiveram dificuldades quanto à dinâmica do jogo, as dúvidas mais frequentes referiam-se as bases nitrogenadas do DNA e do RNA, mas com o desenvolvimento do jogo todas foram superadas e estes alunos foram muito bem nas avaliações referentes ao jogo e ao conteúdo.

Para análise da atividade realizada obtivemos textos produzidos pelos próprios alunos que seguiam a um questionário-roteiro entregue por nós que se referia à dinâmica e estrutura do jogo propriamente dito, enquanto para análise da temática trabalhada, disponibilizamos questões de palavras cruzada referente ao conteúdo do tabuleiro. Analisando o material observamos que apenas quatro participantes não preencheram o jogo de palavras cruzadas de maneira correta, o 
qual abordava a temática referente ao tabuleiro. É um resultado bastante positivo e animador levando em consideração o número de 91 (noventa e um) alunos participantes.

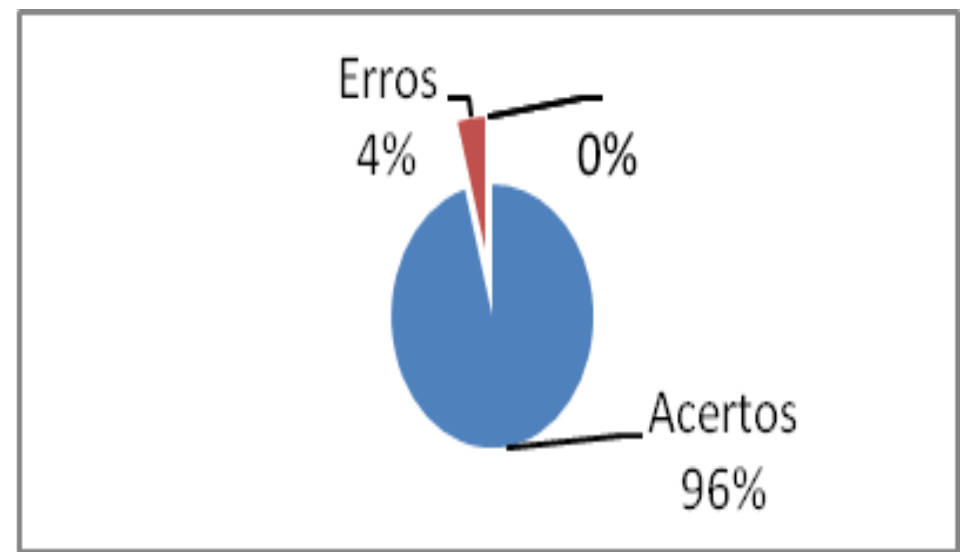

Gráfico 1. Porcentagem de erros e acertos na resolução da palavra cruzada sobre a temática do tabuleiro. Fonte: Arquivo Nathalya Silva.

Segundo Bardin (2009) a Análise de Conteúdo se define como um "conjunto de técnicas de análise das comunicações” (quantitativos ou não) que aposta no rigor do método como forma de não se perder a heterogeneidade de seu objeto, visa obter, por procedimentos, sistemáticos e objetivos de descrição do conteúdo das mensagens, indicadores e conhecimentos relativos às de condições de variáveis inferidas na mensagem. Baseado na ótica de Bardin, sistematizamos os indicadores presente nos textos dos alunos em cinco categorias: I- Aprovação ou rejeição dos jogos; II- Inserir os jogos lúdicos na metodologia dos professores; III- Eficácia na revisão e/ou apresentação de novos conteúdos; IV - Importância de trabalhar em grupo e V- Aquisição do conteúdo.

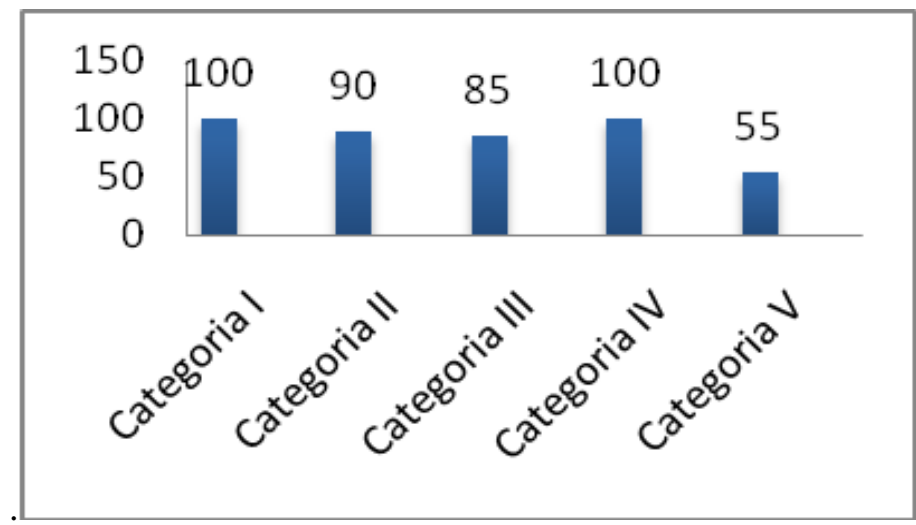

Gráfico 2. Categorias de indicadores presentes nos textos produzidos pelos alunos para analise da aplicabilidade do jogo. Fonte: Arquivo Nathalya Silva.

Analisando a categoria I, verificamos que todos os alunos aprovaram do jogo, o aluno "A" justificou com a seguinte afirmativa: "Com o jogo aprendi mais do que o professor falando", enquanto o aluno B afirmou: "Aprendi muito sobre o DNA e o RNA e fiz isso no modo muito interessante porque foi brincando, foi como um diálogo entre amigos foi bastante 
divertido", alguns alunos se envolveram tanto no jogo que queriam mais tempo para continuar jogando.

Observando a categoria II, constatamos que $90 \%$ dos estudantes expressaram em seus comentários a necessidade da inclusão de atividades lúdicas na metodologia de ensino dos docentes, apresentando justificativas como o aluno C e o aluno D respectivamente: "Os professores devem usar esses tipos de aula mais vezes”, "Eu queria muito que em todas as aulas tivesse isto".

Estudando a categoria III podemos observar a eficácia da atividade lúdica enquanto ferramenta na revisão da aula ministrada como podemos conferir nas justificativas dos alunos $\mathrm{E}$ e F, respectivamente: "O jogo me ajudou bastante porque ainda não havia prestado atenção ou dado tanta importância ao assunto, então o jogo me ajudou a esclarecer várias dúvidas", "O professor está trabalhando esse assunto com a gente, mas não é tão divertido e proveitoso assim”. Os professores que participaram desta atividade acreditam que o jogo auxilia na aprendizagem da matéria que já foi exposta como forma de revisão ou como alternativa para apresentar um conteúdo novo aos alunos para motivá-los a estudar a nova matéria.

Analisando todo o material produzido pelos participantes com enfoque na categoria IV, observamos que todos os alunos perceberam a importância de trabalhar em grupo, pois a turma ficou mais unida e interagia de maneira dinâmica para conseguir alcançar o objetivo do jogo, algumas justificativas foram: "O jogo ajudou alunos que tem vergonha de se relacionar com os colegas de classe” (aluno G), "Conseguimos debater com os colegas sobre DNA e RNA, ajudou muito no aprendizado da gente” (aluno H), segundo Silva, R.M. E Silva, R.C. (2010) “Qualquer interação entre pessoas ou entre pessoas e objetos tem o objetivo de enriquecer, transmitir, ou construir conhecimentos, valores, fazendo parte do processo de Educação", observamos que esses objetivos foram facilmente atingidos durante a aplicação do jogo.

Verificamos na categoria $\mathrm{V}$ que $55 \%$ dos alunos mencionaram em seus textos que o jogo de tabuleiro ensinou para eles algo novo sobre o conteúdo, justificando que: "Aprendi muito sobre o DNA e RNA coisas que eu não conhecia" afirma o aluno I, "Essa brincadeira trouxe muitas informações que eu ainda não sabia” justifica o aluno J.

Quadro 1. Comparativo dos comentários em cada categoria presente nos textos produzidos pelos alunos.

\begin{tabular}{|c|c|c|}
\hline \multicolumn{3}{|r|}{ COMENTÁRIOS SOBRE A DINÂMICA E ESTRUTURA DO JOGO } \\
\hline Categoria & Aluno & Comentário \\
\hline \multirow[b]{2}{*}{ I } & A & "Com o jogo aprendi mais do que o professor falando" \\
\hline & B & $\begin{array}{l}\text { "Aprendi muito sobre o DNA e o RNA e fiz isso no modo muito interessante } \\
\text { porque foi brincando, foi como um diálogo entre amigos foi bastante divertido" }\end{array}$ \\
\hline \multirow{2}{*}{ II } & $\mathrm{C}$ & "Os professores devem usar esses tipos de aula mais vezes"; \\
\hline & $\mathrm{D}$ & “Eu queria muito que em todas as aulas tivesse isto”. \\
\hline \multirow{2}{*}{ III } & $\mathrm{E}$ & $\begin{array}{l}\text { “O jogo me ajudou bastante porque ainda não havia prestado atenção ou dado tanta } \\
\text { importância ao assunto, então o jogo me ajudou a esclarecer várias dúvidas”; }\end{array}$ \\
\hline & $\mathrm{F}$ & $\begin{array}{l}\text { "O professor está trabalhando esse assunto com a gente, mas não é tão divertido e } \\
\text { proveitoso assim" }\end{array}$ \\
\hline \multirow{2}{*}{ IV } & G & $\begin{array}{l}\text { "O jogo ajudou alunos que tem vergonha de se relacionar com os colegas de } \\
\text { classe"; }\end{array}$ \\
\hline & $\mathrm{H}$ & $\begin{array}{l}\text { "Conseguimos debater com os colegas sobre DNA e RNA, ajudou muito no } \\
\text { aprendizado da gente" }\end{array}$ \\
\hline \multirow{2}{*}{ V } & I & "Aprendi muito sobre o DNA e RNA coisas que eu não conhecia” \\
\hline & $\mathrm{J}$ & "Essa brincadeira trouxe muitas informações que eu ainda não sabia” \\
\hline
\end{tabular}

Fonte: Arquivo Nathalya Silva.

Durante o desenvolvimento do jogo os alunos mostravam-se motivados e entusiasmados com a nova proposta apresentada a eles, de uma aula dinâmica e diferente do que estavam 
acostumados. Além disso, os alunos prestavam bastante atenção no que estava sendo explicado e sobre as regras do jogo, foram bastante participativos e até mesmo os alunos considerados mais "trabalhosos" pelos professores receberam de forma positiva a proposta do jogo e mostravam interesse em aprender mais sobre o conteúdo presente no tabuleiro, o resultado foi animador.

A partir da análise dos resultados obtidos, através do jogo de palavras cruzadas e dos textos produzidos pelos alunos constatamos que todos os objetivos propostos na elaboração dos jogos foram alcançados, tendo em vista que a divulgação dos jogos didáticos para auxiliar no ensino e aprendizagem dos conteúdos de lipídios, carboidratos, proteínas e saúde e ácidos nucléicos ocorreu de forma positiva e foi bem recebida por professores e alunos que aprovaram os jogos.

Além disso, todos os participantes da atividade conseguiram perceber os aspectos positivo ao desenvolvimento da aprendizagem na aplicabilidade dos jogos, alguns destes são: exercitam a coletividade, favorecem o raciocínio, proporcionam um aprendizado prazeroso e a interação entre os participantes. E ainda, o jogo correlaciona os conhecimentos do cotidiano do aluno aos conteúdos sobre os riscos da má alimentação à saúde de forma dinâmica. Dentre os jogos didáticos, os jogos de regras como é o jogo de tabuleiro tem um diferencial dos demais, pois consiste na existência de um conjunto de leis (regras), que devem ser cumpridas para obter sucesso no jogo, desse modo há uma simulação do cotidiano do aluno, onde ele poderá encontrar adversas situações de limitação.

Os alunos não ficavam dispersos durante a aplicação do jogo, todos se mostravam envolvidos e entusiasmados com a nova maneira de aprender esses conceitos que são de difícil compreensão.

\section{CONSIDERAÇÕES FINAIS}

Esse trabalho nos mostra que o jogo é um instrumento importante no ensino e na construção do aprendizado por tratar de forma dinâmica e divertida de conteúdos complexos. $\mathrm{O}$ diferencial do lúdico é a aproximação do jogo às teorias, e não apenas uma listagem dissociada de receitas de brincadeiras, e a proposição de alternativas de lugar para o jogo. Sua eficácia no processo ensino-aprendizado foi facilmente observada durante a aplicabilidade do jogo, e depois confirmada nas citações feitas por alunos e professores na produção de seus comentários.

Concordamos quando a autora Kishiomoto (1996) afirma que devemos valorizar "os jogos na educação, ou seja, brinquedos e brincadeiras como formas privilegiadas de desenvolvimento e apropriação, conhecimento, portanto, instrumentos indispensáveis da prática pedagógica e componente relevante de propostas curriculares”, pois a atividade realizada nos mostra que jogando o aluno atinge um aprendizado significativo e prazeroso e aprende o valor do trabalho em grupo.

Sobre as contribuições dessa experiência em nossa formação docente entendemos que a democratização do ensino passa pela sua formação, sua valorização profissional, suas condições de trabalho, pesquisas e experiências inovadoras têm apontado para a importância do investimento no desenvolvimento profissional dos professores. O desenvolvimento profissional envolve formação inicial e contínua articuladas a um processo de valorização indenitária e profissional dos professores.

As agências de fomento federais como a CAPES tem lançado editais que buscam valorizar os cursos de formação de professores (licenciaturas), estimular inovações nas salas de aula e aproximar a Universidade da Escola de Educação Básica, nessa perspectiva promovendo melhorias nos dois segmentos.

Essa oportunidade que o PIBID (Programa Institucional de Bolsa de Iniciação à Docência) nos proporciona de estar nas salas de aula de escolas da rede pública de ensino conhecendo a realidade das mesmas para que possamos intervir de modo a auxiliar professores e alunos em seu dia-dia é, sem sombra de dúvidas, um diferencial positivo em nossa formação docente, pois enquanto estamos na academia continuando o curso em licenciatura também 
estamos em sala de aula pondo em prática os conceitos e perspectivas que discutimos em nossas reuniões semanais do PIBID-BIOLOGIA/UEPB.

Esperamos que esta pesquisa impulsione outros estudos nessa área como também a elaboração de novos jogos lúdicos para que não limite-se apenas a teoria, mas que seja uma pratica nas escolas publicas e privadas e ainda que os professores tomem conhecimento desse estudo e adotem esta estratégia de ensino que é bastante positiva para todos os participantes.

\section{REFERÊNCIAS}

BARDIN, L. Análise de Conteúdo. Lisboa, Portugal; Edições 70, LDA, 2009.

BORDENAVE, J.; PEREIRA, A. Estratégias de Ensino-aprendizagem. 30 ed. Petrópolis: Vozes, 2010.

BRASIL. Lei de Diretrizes e Bases da Educação Nacional - 9.394/1996 (LDB). 1996.

BRASIL. Ministério da Educação. Secretaria de Educação Básica. Orientações Curriculares para o Ensino Médio: Ciências da natureza, matemática e suas tecnologias. Brasília: MEC/SEB, 2006.

BRASIL. Orientações educacionais complementares aos Parâmetros Curriculares Nacionais (PCN+). 2000.

KISHIOMOTO, T. M. Jogo, brinquedo, brincadeira e a educação. 11 ed. São Paulo: Cortez, 1996.

SILVA, R. M.; SILVA, R. C. O lúdico enquanto estratégia didática para as ciências. 2010. 